\title{
Pathogens vectored by the tick, Dermacentor reticulatus, in endemic regions and zones of expansion in Poland
}

\author{
Ewa J. Mierzejewska ${ }^{1 *}$, Agnieszka Pawełczyk², Marek Radkowski ${ }^{2}$, Renata Welc-Falęciak and Anna Bajer ${ }^{1}$
}

\begin{abstract}
Background: Dermacentor reticulatus plays an important role in the maintenance of pathogens of medical and veterinary importance in the environment. Currently two isolated populations of $D$. reticulatus are present in Poland -Western and Eastern. The range of the Eastern population covers endemic areas in eastern Poland but this population is expanding westwards creating an expansion zone in the centre of the country. The expansion zone in western Poland is occupied by the recently discovered Western population, spreading eastwards.

Methods: Questing adult ticks $(n=2585)$ were collected in 2012-2014 in endemic regions of north-eastern (Warmińsko-Mazurskie Voivodeship) and central Poland (Masovian Voivodeship) and in the expansion zones in central and western Poland, in the region between the Vistula River and the western border of the country. Amplification of Babesia, Rickettsia spp. and Borrelia burgdorferi sensu lato DNAs was performed using specific starters. RNA of the TBE virus was detected using RT-PCR and representative PCR products were sequenced and compared with sequences deposited in GenBank.

Results: Of the total 2585 examined ticks, 1197 (46.3\%) were infected with at least one pathogen. Overall prevalence of pathogens was $4.18 \%$ (108/2585) for Babesia spp., $44.10 \%$ (1140/2585) for Rickettsia spp., $0.09 \%$ (1/1107) for Borrelia afzelii and $7.6 \%$ (7/92) for TBEV. Sequence analysis of DNA showed $99.86 \%$ similarity to R. raoulti and $99.81 \%$ to $B$. canis. One male from north-eastern Poland was infected with B. microti.

Prevalence of $R$. raoulti was highest in the Western population (52.03 \%) and lowest in the Eastern population in north-eastern Poland (34.18\%). Babesia canis was not detected in 592 ticks collected in the Western population, while in the Eastern population overall prevalence was $5.42 \%$. There were significant differences in the prevalence of $B$. canis between tick samples from northern (0.68\%), central (1.18\%) and southern (14.8\%) areas of the expansion zone in central Poland.
\end{abstract}

Conclusions: Our study found significant differences between the range and prevalence of vectored pathogens in $D$. reticulatus from the endemic areas and newly inhabited expansion zones. The differences were likely associated with the different time of settlement or 'source' of ticks populations, the Eastern and the Western one.

Keywords: Dermacentor reticulatus, Pathogens, Babesia canis, Rickettsia raoulti, Borrelia burgdorferi s.l, Poland, expansion

\footnotetext{
* Correspondence: e.mierzejewska@biol.uw.edu.pl

'Department of Parasitology, Institute of Zoology, Faculty of Biology,

University of Warsaw, 1 Miecznikowa Street, 02-096 Warsaw, Poland

Full list of author information is available at the end of the article
} 


\section{Background}

Dermacentor reticulatus (Fabricius, 1974) is the main vector of Babesia canis [1-3], the aetiological agent of canine babesiosis, responsible for one of the most threatening infectious diseases of dogs in endemic regions [4-6]. D. reticulatus has been observed to spread in many European countries over the last two decades, and this is a subject of considerable concern for the veterinary services. In some countries considered to be free of $D$. reticulatus, autochthonous cases of canine babesiosis were the first sign of appearance of this tick, e.g., Belgium [7] and Netherland [8]. Until the 1990's foci of this tick in Poland were known to exist almost exclusively in north-eastern parts of the country [9-12]. The area between the Vistula River and the western border of the country was considered to be a territory free of $D$. reticulatus, splitting its range into Western European and Eastern macro regions [13-15]. In the late 1990's D. reticulatus ticks were found on dogs in the Masovian Voivodeship, east of the Vistula River (own unpublished data). Currently these areas are considered to be endemic for $D$. reticulatus and canine babesiosis [5, 6]. At the beginning of $\mathrm{XXI}^{\text {th }}$ century canine babesiosis had spread further and was commonly diagnosed in dogs living west of the Vistula River, in the vicinity of Warsaw $[4,5,16]$. Zygner and Wędrychowicz [17] confirmed the frequent occurrence of $D$. reticulatus in the Warsaw region, first on dogs and subsequently these ticks were collected from vegetation $[18,19]$. Recently new foci of $D$. reticulatus have been found in western Poland, in the area historically free of this tick [20-22].

In our recent study, we discovered a large and stable population of this tick in western Poland [23]. Moreover, the monitoring of $D$. reticulatus in the extensive region between the Vistula River and the western border of the country in 2012-2014 has confirmed expansion of this species westwards, west of the Vistula River and eastwards in western Poland [23]. Those two expansion zones are separated by 'the gap' in the range - the area where $D$. reticulatus has so far never been found. This gap splits populations of this species in Poland into two separated populations - Western and Eastern. The discoveries of a large population in western Poland and associated active expansion zones led to pertinent questions about the range and prevalence of important tick-borne pathogens (TBP's) vectored by ticks from different regions of the country.

The host spectrum for $D$. reticulatus is wide and differs at every life stage. Larvae and nymphs are endophilic and parasitize small mammals living in burrows. Adults are exophilic and feed on large ungulates, carnivores, horses or wild boars [24-28]. This tick species attacks humans very rarely $[29,30]$. However, D. reticulatus plays an important role in the maintenance of TBP's of veterinary and medical importance in the environment and their transmission between vertebrate hosts that are susceptible to infection or serve as efficient reservoirs. Based on detection of pathogen specific DNA, microorganisms known to cause diseases of animals and humans, have been detected in ticks of this species, e.g., Rickettsia spp., TBEV, Borrelia burgdorferi s.l., Anaplasma phagocytophlium, Bartonella spp. Coxiella burnetti, Francisella tularensis [31-34]. Nevertheless, the prevalence of some of these pathogens can be very low and the status of $D$. reticulatus as their vector has been questioned [35-37]. In recent years a high prevalence of tick-borne encephalitis virus (TBEV) has been demonstrated in ticks in two studies from eastern and central Poland [38, 39], a virus to which dogs are known to be susceptible, as first demonstrated by Weissenböck et al. [40] and then confirmed by Bajer et al. [41].

As far as we are aware, the prevalence of pathogens of veterinary and medical importance in ticks has not been investigated in western Poland and studies on the infection rate of pathogens other than TBEV [39] in questing ticks from central Poland have not yet been conducted on a large scale. The discovery of several new locations of $D$. reticulatus in two expansion zones west of the Vistula River and in western Poland [23] has created a unique opportunity to study the prevalence of pathogens in two distinct, geographically separated populations of this tick species. Importantly, the first recorded occurrence of $D$. reticulatus in the eastern and western regions was markedly different, raising questions about the contrasting prevalence rates of pathogens in ticks from regions that have varied over the years in the duration over which they have been inhabited by this tick species.

The aims of the present study were (1) to compare prevalence of Babesia and Rickettsia spp. between two tick populations and between endemic and newly inhabited regions of Poland, (2) to assess prevalence of TBEV in endemic regions of central Poland (Masovian Voivodeship) and (3) to study the role of $D$. reticulatus in transmission of B. burgdorferi s.l.

\section{Methods}

\section{Collection sites}

Adult questing ticks were collected from September 2011 to May 2014. Additionally, 96 ticks (52 females and 44 males) collected in spring 2009 in Kury (Eastern population, endemic region, east of the Vistula River) were included in the study. Ticks were collected in typical habitats: fallow lands and meadows covered by vegetation higher than $60 \mathrm{~cm}$, located close to water reservoirs and water courses. Sites for tick collection were selected across Poland in four regions that differ in time of appearance/ settlement of $D$. reticulatus ticks (Fig. 1). Two of these regions were part of the Eastern population, situated in endemic areas of the Warmińsko-Mazurskie Voivodeship where the earliest reported foci of $D$. reticulatus have been 


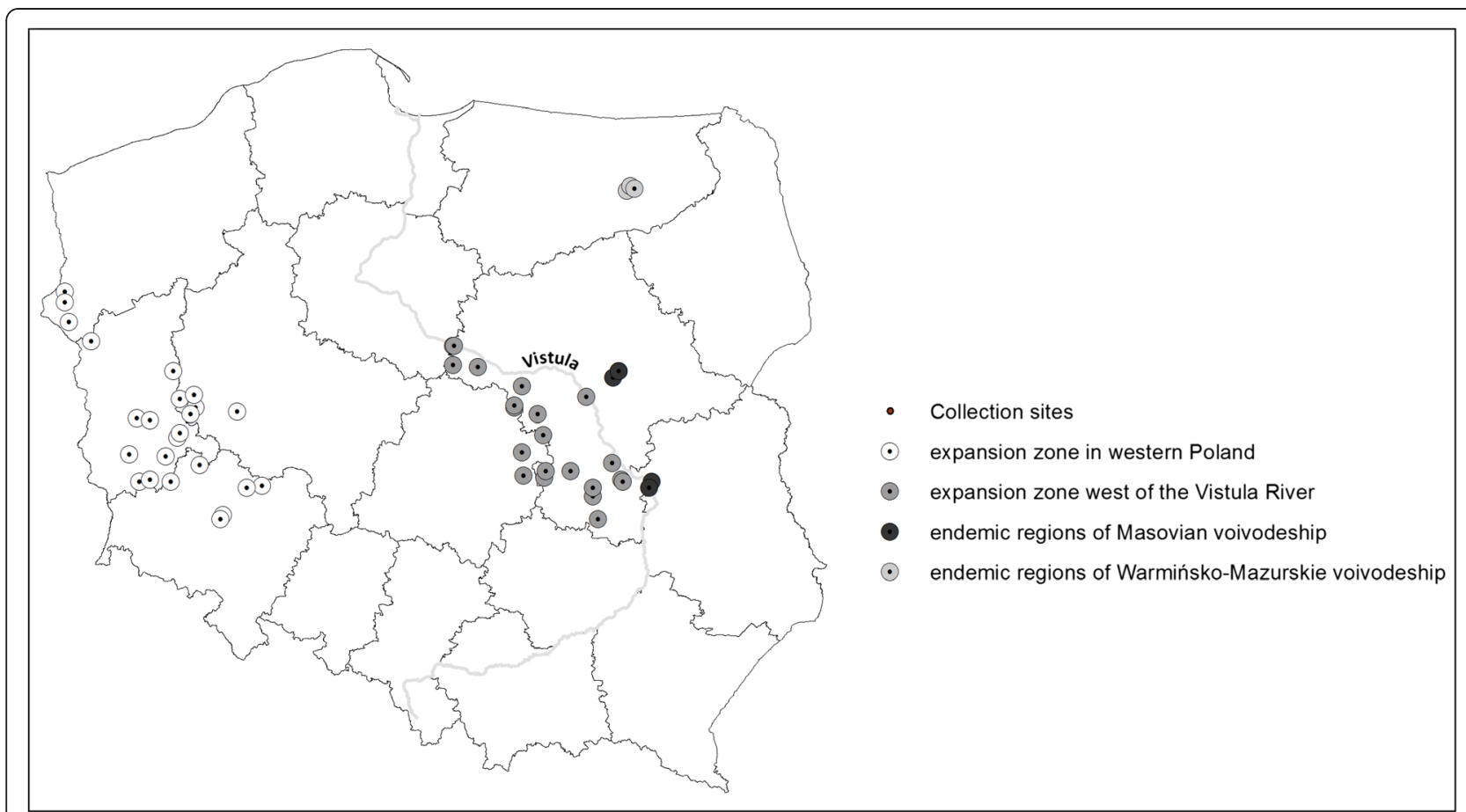

Fig. 1 The location of all the collection sites utilized in the current study

documented and Masovian Voivodeship, east of the Vistula River, where presence of this tick species is known only from the late 1990's. A further two regions were situated in two expansion zones - territories west of the Vistula in central Poland (expanding part of the Eastern population known to exist only from the beginning of XXI ${ }^{\text {th }}$ century) and areas in western Poland (recently discovered eastwardly expanding Western population). All the sites utilized in this study have been described in detail in Mierzejewska et al. [23]. Collection sites $(n=39)$ in endemic regions $(n=9)$ and expansion zones $(n=30)$ are shown on Fig. 1. A detailed list of adult D. reticulatus ticks collected at each site is shown in Table 1.

\section{Tick collection}

Ticks were collected by conventional dragging in the morning (9:00-12:00) or in the afternoon (from 15:00 to the dusk) from the middle of March to early May and from the middle of September to the beginning of November each year (a detailed description is provided in Mierzejewska et al. 2015 [23]). Collected ticks were preserved in $70 \%$ ethanol or were stored in a cooler at a temperature of $+8{ }^{\circ} \mathrm{C}$. Tick species and sex were determined using a stereo microscope.

\section{DNA and RNA isolation}

DNA was extracted from 2585 ticks using the QIAamp DNA mini kit (QIAGEN, Germany) following the manufacturer's instructions. Every tick was cut by half along its longitudinal axis so as to provide the optimal weight of each sample recommended by the manufacturer. Total DNA was eluted in $160.0 \mu \mathrm{L}$ of elution buffer. Extracted DNA was stored in $-20{ }^{\circ} \mathrm{C}$ for further procedures. RNA was extracted from 92 ticks collected in endemic regions of the Masovian Voivodeship, east of the Vistula River. RNA was extracted from live ticks using AllPrep DNA/ RNA Mini Kit (QIAGEN). To obtain cDNA, $5.0 \mu \mathrm{L}$ of the RNA preparation were reverse-transcribed in a $15.0 \mu \mathrm{L}$ of final reaction volume containing $3.0 \mu \mathrm{l}$ of $25 \mathrm{mM} \mathrm{MgCl} 2$ (Thermo Scientific), $1.5 \mu \mathrm{l}$ of 10xPCR Buffer, $1.5 \mu \mathrm{l}$ of $10 \mathrm{mM}$ dNTP (Invitrogen, USA), $0.5 \mu \mathrm{l}$ of $50.0 \mu \mathrm{M}$ random hexamer primers (Roche, Indianapolis, USA), $0.75 \mu \mathrm{l}$ of 0.1 M DTT (Invitrogen), 20.0 U M-MLV reverse transcriptase (Invitrogen). The reverse transcription was performed at $37{ }^{\circ} \mathrm{C}$ for $30 \mathrm{~min}$, at $95^{\circ} \mathrm{C}$ for $5 \mathrm{~min}$ and at $4{ }^{\circ} \mathrm{C}$ for $5 \mathrm{~min}$. Both RNA and cDNA were stored in $-80^{\circ} \mathrm{C}$ for further analysis.

\section{DNA amplification}

The extracted DNA was subjected to PCR with the specific primers. Primers and reaction conditions were as previously described by the original authors mentioned in detailed description below. Each reaction was carried out in a $20.0 \mu \mathrm{l}$ of the final PCR mixture volume containing $0.33 \mathrm{mM}$ dNTPs (Eurobio, Lille, France), $2.0 \mathrm{mM} \mathrm{MgCl}$, $1 \times$ PCR buffer, 1.0 U DreamTaq polymerase (Fermentas). The amount of primers used and the volume of template DNA varied between protocols for different pathogens as 
Table 1 Number of adult ticks D. reticulatus collected at each site

\begin{tabular}{|c|c|c|c|c|c|c|c|c|c|c|c|c|c|c|}
\hline \multirow[t]{4}{*}{ Region } & \multirow[t]{4}{*}{ Site of ticks collection } & \multicolumn{12}{|c|}{ Year, season and sex of tick } & \multirow[t]{4}{*}{ Total } \\
\hline & & \multicolumn{3}{|c|}{2011} & \multicolumn{3}{|c|}{2012} & \multicolumn{3}{|c|}{2013} & \multicolumn{3}{|c|}{2014} & \\
\hline & & \multicolumn{2}{|l|}{$\mathrm{A}$} & \multirow[t]{2}{*}{$\Sigma$} & \multicolumn{2}{|c|}{$\mathrm{S}+\mathrm{A}$} & \multirow[t]{2}{*}{$\Sigma$} & \multicolumn{2}{|l|}{$S+A$} & \multirow[t]{2}{*}{$\Sigma$} & \multicolumn{2}{|l|}{$s$} & \multirow[t]{2}{*}{$\Sigma$} & \\
\hline & & q & $\hat{0}$ & & q & 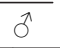 & & q & $\hat{0}$ & & q & $\pi$ & & \\
\hline \multirow[t]{13}{*}{ Masovian endemic } & Dąbrowica & 24 & 16 & 40 & 10 & 16 & 26 & 42 & 27 & 69 & 40 & 24 & 64 & 199 \\
\hline & N 52.357819 & & & & & & & & & & & & & \\
\hline & E 21.453904 & & & & & & & & & & & & & \\
\hline & Kury & 3 & 4 & 7 & 12 & 16 & 28 & $\mathrm{nc}$ & $\mathrm{nc}$ & $\mathrm{nc}$ & 17 & 10 & 27 & 62 \\
\hline & N 52.413677 & & & & & & & & & & & & & \\
\hline & E 21.512028 & & & & & & & & & & & & & \\
\hline & Miąse & $\mathrm{nc}$ & $\mathrm{nc}$ & $\mathrm{nc}$ & $\mathrm{nc}$ & $\mathrm{nc}$ & $\mathrm{nc}$ & 10 & 5 & 15 & 0 & 1 & 1 & 16 \\
\hline & N 52.397716 & & & & & & & & & & & & & \\
\hline & E 21.445945 & & & & & & & & & & & & & \\
\hline & Stoski & 4 & 10 & 14 & 49 & 56 & 105 & 140 & 41 & 181 & 40 & 11 & 51 & 351 \\
\hline & N 52.409226 & & & & & & & & & & & & & \\
\hline & E 21.509125 & & & & & & & & & & & & & \\
\hline & $\Sigma$ & 31 & 30 & 61 & 71 & 88 & 159 & 192 & 73 & 265 & 97 & 46 & 143 & 628 \\
\hline \multirow[t]{16}{*}{ Warmińsko-Mazurskie endemic } & Dziubiele & 12 & 8 & 20 & 28 & 31 & 59 & 6 & 10 & 16 & 32 & 39 & 71 & 166 \\
\hline & N 53.814619 & & & & & & & & & & & & & \\
\hline & E 21.704191 & & & & & & & & & & & & & \\
\hline & Łuknajno & 17 & 30 & 47 & 27 & 5 & 32 & 12 & 11 & 23 & $\mathrm{nc}$ & $\mathrm{nc}$ & $\mathrm{nc}$ & 102 \\
\hline & N 53.802309 & & & & & & & & & & & & & \\
\hline & E 21.644787 & & & & & & & & & & & & & \\
\hline & Osa & 18 & 16 & 34 & 7 & 0 & 7 & 19 & 15 & 34 & 22 & 6 & 28 & 103 \\
\hline & N 53.820064 & & & & & & & & & & & & & \\
\hline & E 21.650590 & & & & & & & & & & & & & \\
\hline & Stawek & 8 & 14 & 22 & 5 & 3 & 8 & 12 & 5 & 17 & $\mathrm{nc}$ & $\mathrm{nc}$ & $\mathrm{nc}$ & 47 \\
\hline & N 53.794089 & & & & & & & & & & & & & \\
\hline & E 21.616050 & & & & & & & & & & & & & \\
\hline & Urwitałt & 8 & 10 & 18 & 8 & 11 & 19 & 14 & 5 & 19 & $\mathrm{nc}$ & $\mathrm{nc}$ & $\mathrm{nc}$ & 56 \\
\hline & N 53.809755 & & & & & & & & & & & & & \\
\hline & E 21.645224 & & & & & & & & & & & & & \\
\hline & $\Sigma$ & 63 & 78 & 141 & 75 & 50 & 125 & 63 & 46 & 109 & 54 & 45 & 99 & 474 \\
\hline Expansion zone in central Poland & Northern area & $\mathrm{nc}$ & $\mathrm{nc}$ & $\mathrm{nc}$ & $\mathrm{nc}$ & $\mathrm{nc}$ & $\mathrm{nc}$ & 1 & 3 & 4 & $\mathrm{nc}$ & $\mathrm{nc}$ & $\mathrm{nc}$ & 4 \\
\hline
\end{tabular}


Table 1 Number of adult ticks D. reticulatus collected at each site (Continued)

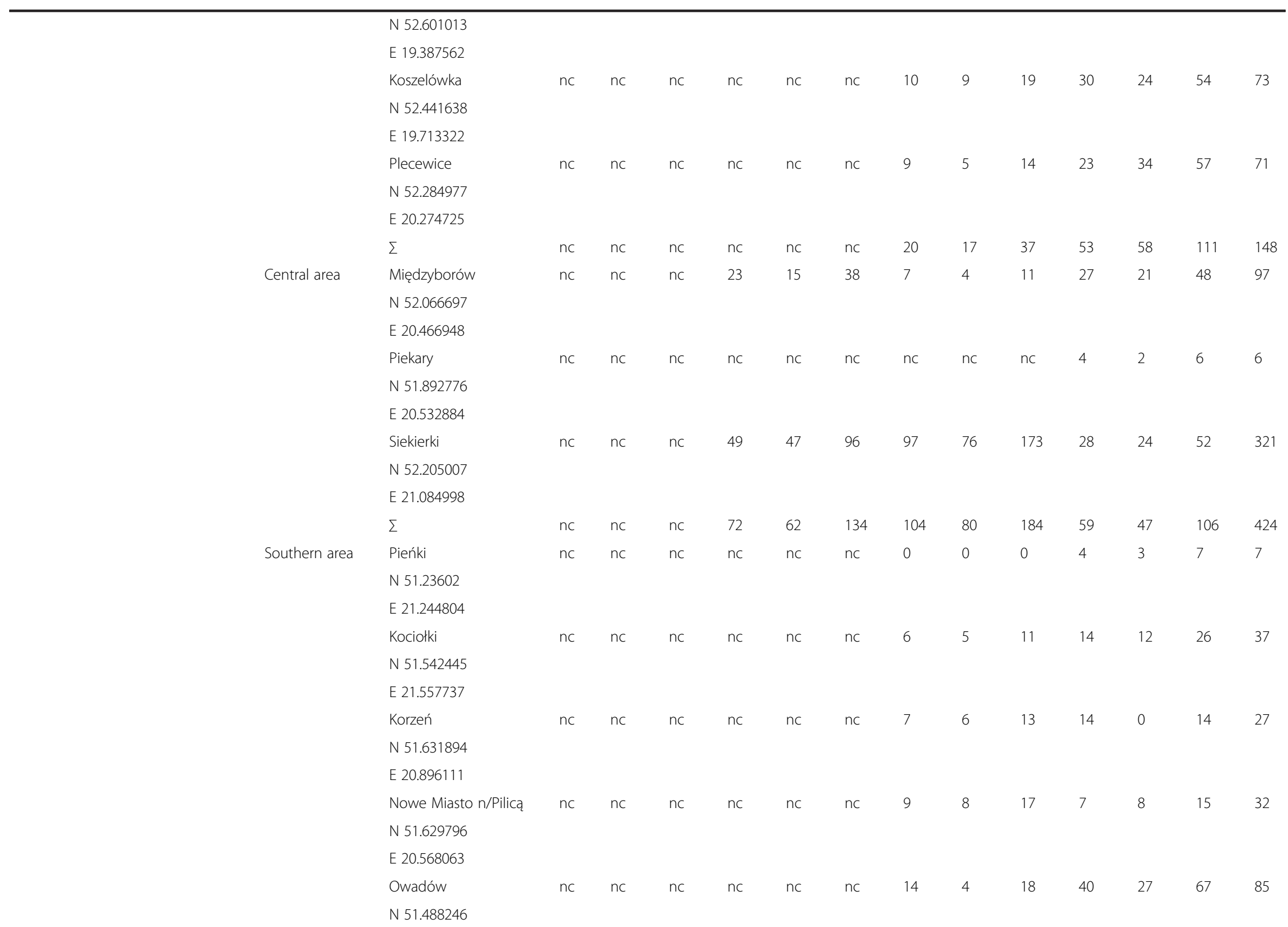


Table 1 Number of adult ticks D. reticulatus collected at each site (Continued)

\begin{tabular}{|c|c|c|c|c|c|c|c|c|c|c|c|c|c|c|c|}
\hline & & E 21.175258 & & & & & & & & & & & & & \\
\hline & & Radom & $\mathrm{nc}$ & $\mathrm{nc}$ & $\mathrm{nc}$ & $\mathrm{nc}$ & $\mathrm{nc}$ & $\mathrm{nc}$ & 4 & 5 & 9 & 7 & 0 & 7 & 16 \\
\hline & & N 51.429317 & & & & & & & & & & & & & \\
\hline & & E 21.165899 & & & & & & & & & & & & & \\
\hline & & Rawa Maz. & nc & nc & $\mathrm{nc}$ & nc & $\mathrm{nc}$ & $\mathrm{nc}$ & $\mathrm{nc}$ & nc & $\mathrm{nc}$ & 6 & 3 & 9 & 9 \\
\hline & & N 51.763742 & & & & & & & & & & & & & \\
\hline & & E 20.274813 & & & & & & & & & & & & & \\
\hline & & Ryczywół & nc & $\mathrm{nc}$ & $\mathrm{nc}$ & $\mathrm{nc}$ & $\mathrm{nc}$ & $\mathrm{nc}$ & 5 & 3 & 8 & $\mathrm{nc}$ & $\mathrm{nc}$ & $\mathrm{nc}$ & 8 \\
\hline & & N 51.690792 & & & & & & & & & & & & & \\
\hline & & E 21.417891 & & & & & & & & & & & & & \\
\hline & & Rzeczyca & nc & $\mathrm{nc}$ & $\mathrm{nc}$ & $\mathrm{nc}$ & $\mathrm{nc}$ & $\mathrm{nc}$ & $\mathrm{nc}$ & $\mathrm{nc}$ & $\mathrm{nc}$ & 2 & 0 & 2 & 2 \\
\hline & & N 51.571705 & & & & & & & & & & & & & \\
\hline & & E 20.237232 & & & & & & & & & & & & & \\
\hline & & $\Sigma$ & $\mathrm{nc}$ & $\mathrm{nc}$ & $\mathrm{nc}$ & $\mathrm{nc}$ & $\mathrm{nc}$ & $\mathrm{nc}$ & 45 & 31 & 76 & 94 & 53 & 147 & 223 \\
\hline Expansion zone in western Poland & Northern area & Chojna & nc & $\mathrm{nc}$ & $\mathrm{nc}$ & 2 & 5 & 7 & 13 & 14 & 27 & $\mathrm{nc}$ & $\mathrm{nc}$ & $\mathrm{nc}$ & 34 \\
\hline & & N 52.941048 & & & & & & & & & & & & & \\
\hline & & E 14.443807 & & & & & & & & & & & & & \\
\hline & & Mieszkowice & nc & $\mathrm{nc}$ & $\mathrm{nc}$ & $\mathrm{nc}$ & $\mathrm{nc}$ & $\mathrm{nc}$ & 8 & 5 & 13 & $\mathrm{nc}$ & $\mathrm{nc}$ & $\mathrm{nc}$ & 13 \\
\hline & & N 52.757022 & & & & & & & & & & & & & \\
\hline & & E 14.504899 & & & & & & & & & & & & & \\
\hline & & $\Sigma$ & nc & $\mathrm{nc}$ & $\mathrm{nc}$ & 2 & 5 & 7 & 21 & 19 & 40 & $\mathrm{nc}$ & $\mathrm{nc}$ & $\mathrm{nc}$ & 47 \\
\hline & Central area & Konotop & nc & $\mathrm{nc}$ & $\mathrm{nc}$ & $\mathrm{nc}$ & $\mathrm{nc}$ & $\mathrm{nc}$ & 1 & 0 & 1 & $\mathrm{nc}$ & $\mathrm{nc}$ & $\mathrm{nc}$ & 1 \\
\hline & & N 51.925143 & & & & & & & & & & & & & \\
\hline & & E 15.897403 & & & & & & & & & & & & & \\
\hline & & Kościan & nc & $\mathrm{nc}$ & $\mathrm{nc}$ & $\mathrm{nc}$ & $\mathrm{nc}$ & $\mathrm{nc}$ & 6 & 6 & 12 & $\mathrm{nc}$ & $\mathrm{nc}$ & $\mathrm{nc}$ & 12 \\
\hline & & N 52.096831 & & & & & & & & & & & & & \\
\hline & & E 16.635880 & & & & & & & & & & & & & \\
\hline & & Krępa & nc & $\mathrm{nc}$ & $\mathrm{nc}$ & 40 & 41 & 81 & 0 & 0 & 0 & 18 & 16 & 34 & 115 \\
\hline & & N 52.010798 & & & & & & & & & & & & & \\
\hline & & E 15.542329 & & & & & & & & & & & & & \\
\hline & & Nietków & nc & $\mathrm{nc}$ & $\mathrm{nc}$ & 1 & 0 & 1 & $\mathrm{nc}$ & $\mathrm{nc}$ & $\mathrm{nc}$ & $\mathrm{nc}$ & $\mathrm{nc}$ & $\mathrm{nc}$ & 1 \\
\hline & & N 52.030810 & & & & & & & & & & & & & \\
\hline & & E 15.345025 & & & & & & & & & & & & & \\
\hline
\end{tabular}


Table 1 Number of adult ticks D. reticulatus collected at each site (Continued)

\begin{tabular}{|c|c|c|c|c|c|c|c|c|c|c|c|c|c|c|c|}
\hline & & Obra & $\mathrm{nc}$ & $\mathrm{nc}$ & $\mathrm{nc}$ & 0 & 0 & 0 & 9 & 3 & 12 & 4 & 0 & 4 & 16 \\
\hline & & N 52.069111 & & & & & & & & & & & & & \\
\hline & & E 16.041058 & & & & & & & & & & & & & \\
\hline & & Polkowiczki & nc & $\mathrm{nc}$ & $\mathrm{nc}$ & 26 & 16 & 42 & $\mathrm{nc}$ & $\mathrm{nc}$ & $\mathrm{nc}$ & $\mathrm{nc}$ & $\mathrm{nc}$ & $\mathrm{nc}$ & 42 \\
\hline & & N 51.549555 & & & & & & & & & & & & & \\
\hline & & E 15.512411 & & & & & & & & & & & & & \\
\hline & & Popowice & nc & $\mathrm{nc}$ & $\mathrm{nc}$ & 21 & 11 & 32 & 42 & 38 & 80 & 34 & 14 & 48 & 160 \\
\hline & & N 51.755451 & & & & & & & & & & & & & \\
\hline & & E 15.251825 & & & & & & & & & & & & & \\
\hline & & Przemków & $\mathrm{nc}$ & $\mathrm{nc}$ & $\mathrm{nc}$ & 48 & 27 & 75 & $\mathrm{nc}$ & $\mathrm{nc}$ & $\mathrm{nc}$ & $\mathrm{nc}$ & $\mathrm{nc}$ & $\mathrm{nc}$ & 75 \\
\hline & & N 51.534175 & & & & & & & & & & & & & \\
\hline & & E 15.778345 & & & & & & & & & & & & & \\
\hline & & Rudawica & $\mathrm{nc}$ & $\mathrm{nc}$ & $\mathrm{nc}$ & 3 & 0 & 3 & $\mathrm{nc}$ & $\mathrm{nc}$ & $\mathrm{nc}$ & $\mathrm{nc}$ & $\mathrm{nc}$ & $\mathrm{nc}$ & 3 \\
\hline & & N 51.536233 & & & & & & & & & & & & & \\
\hline & & E 15.396157 & & & & & & & & & & & & & \\
\hline & & Sierczynek & $\mathrm{nc}$ & $\mathrm{nc}$ & $\mathrm{nc}$ & $\mathrm{nc}$ & $\mathrm{nc}$ & $\mathrm{nc}$ & 3 & 4 & 7 & $\mathrm{nc}$ & $\mathrm{nc}$ & $\mathrm{nc}$ & 7 \\
\hline & & N 52.380312 & & & & & & & & & & & & & \\
\hline & & E 15.797783 & & & & & & & & & & & & & \\
\hline & & $\Sigma$ & $\mathrm{nc}$ & $\mathrm{nc}$ & $\mathrm{nc}$ & 139 & 95 & 234 & 61 & 51 & 112 & 56 & 30 & 86 & 432 \\
\hline & Southern area & Kawice & $\mathrm{nc}$ & $\mathrm{nc}$ & $\mathrm{nc}$ & $\mathrm{nc}$ & $\mathrm{nc}$ & $\mathrm{nc}$ & 60 & 16 & 76 & 21 & 12 & 33 & 109 \\
\hline & & N 51.244003 & & & & & & & & & & & & & \\
\hline & & E 16.428092 & & & & & & & & & & & & & \\
\hline & & Klucze & $\mathrm{nc}$ & $\mathrm{nc}$ & $\mathrm{nc}$ & 2 & 0 & 2 & $\mathrm{nc}$ & $\mathrm{nc}$ & $\mathrm{nc}$ & $\mathrm{nc}$ & $\mathrm{nc}$ & $\mathrm{nc}$ & 2 \\
\hline & & N 51.667118 & & & & & & & & & & & & & \\
\hline & & E 16.149976 & & & & & & & & & & & & & \\
\hline & & Lubiąż & nc & $\mathrm{nc}$ & $\mathrm{nc}$ & 0 & 2 & 2 & $\mathrm{nc}$ & $\mathrm{nc}$ & $\mathrm{nc}$ & $\mathrm{nc}$ & $\mathrm{nc}$ & $\mathrm{nc}$ & 2 \\
\hline & & N 51.260855 & & & & & & & & & & & & & \\
\hline & & E 16.461059 & & & & & & & & & & & & & \\
\hline & & $\Sigma$ & nc & $\mathrm{nc}$ & $\mathrm{nc}$ & 2 & 2 & 4 & 60 & 16 & 76 & 21 & 12 & 33 & 113 \\
\hline Total & & & 94 & 108 & 202 & 361 & 302 & 663 & 566 & 333 & 899 & 434 & 291 & 725 & 2489 \\
\hline
\end{tabular}


described in detail below. All negative controls were performed in the absence of template DNA. Amplicons were visualized with Midori Green stain (Nippon Genetics Europe $\mathrm{GmbH}$ ) following electrophoresis in $2 \%$ agarose gels. Amplicons were purified and sequenced by a private company (Genomed S.A., Poland). The resulting sequences were compared with sequences deposited in the GenBank database (http://blast.ncbi.nlm.nih.gov/Blast.cgi). DNA sequence alignments were conducted using the program Bioedit 7.1.

\section{Babesia spp. and Rickettsia spp.}

The DNA amplification was carried out in $20 \mu \mathrm{l}$ of the final PCR mixture contained $1.0 \mu \mathrm{M}$ of each primer. In the protocol for Rickettsia spp. primers CS409/ Rp1258 [42] were used to produce a $\sim 750 \mathrm{bp}$ fragment of glt A gene. Nested - PCR reaction targeting 18S rRNA was performed to detect genetic material of Babesia spp. In the first reaction with the outer primers CRYPTO R/ CRYPTO F [43] fragment of length 1200 bp was amplified. For the second reaction two different pairs of primers were used to obtain maximum reliable results: Bab GR2/ Bab GF2 [44] or Piro A/ Piro B [45] to produce a 550 bp or $\sim 400$ bp fragment respectively. For the protocol for Rickettsia spp. and for the first reaction with the outer primers in the protocol for Babesia spp., the template DNA volume was $2.0 \mu \mathrm{l}$. The second reaction with the inner primers in the protocol for Babesia spp. was carried out with $1.0 \mu \mathrm{l}$ of the post-first reaction mixture as the template DNA. The positive control in the Babesia spp. protocol was the DNA of Babesia microti Kings Collage strain [46]. The positive control in the Rickettsia spp. protocol was the DNA of $R$. helvetica [47].

\section{Borrelia burgdorferi s.l.}

Detection of B. burgdorferi s.l. was conducted in DNA extracted from 1107 ticks: 262 ticks collected in endemic regions in central Poland, 192 in endemic regions in Warmińsko-Mazurskie Voivodeship, 427 in non-endemic regions in central Poland (expansion zone west of the Vistula River), 228 in non-endemic regions in western Poland. For detection of this species, nested - PCR reaction targeting fla gene fragment (774 bp) was performed in $20.0 \mu \mathrm{l}$ of the final PCR mixture contained $0.2 \mu \mathrm{M}$ of each primer [48]. For the first reaction with outer primers 132f/ $905 \mathrm{r}$ the template DNA volume was $2.0 \mu \mathrm{l}$. In second reaction with inner primers 220f/ 824r, $1.0 \mu \mathrm{l}$ of 10-times diluted post-first reaction mixture was used as the template DNA to produce the final product of $605 \mathrm{bp}$.

The positive control was the DNA of B. burgdorferi sensu stricto kindly provided by Dr. Nataliia Rudenko and Dr. Maryna Golovchenkofrom Biology
Centre AS CR, Institute of Parasitology, Ceske Budejovice, Czech Republic.

\section{TBEV}

For detection of TBEV, cDNAs were screened by RealTime PCR. Reactions were carried out using the LightCycler FastStart DNA Master Sybr Green I Kit (Roche) in a total volume of $20.0 \mu \mathrm{l}$ containing $5.0 \mu \mathrm{M}$ of each primer TBEV_2F or TBEV_2R [49] and $2.0 \mu \mathrm{l}$ of template cDNA. The final product was 195 bp fragment of $16 \mathrm{~S}$ rRNA. The positive control was the RNA of TBEV Sofin strain kindly provided by Dr. Bernd Hoffmann from the Institute of Diagnostic Virology, Friedrich Loeffler Institute, Greifswald-Insel Riems, Germany.

\section{Statistical analysis}

The prevalence of $B$. canis and $R$. raoulti were analyzed by maximum likelihood techniques based on log linear analysis of contingency tables, implemented by the software package, SPSS v. 21. Four statistical models were constructed to analyze the effect of different categories of regions on the prevalence of B. canis and $R$. raoulti: (1) between Eastern and Western tick populations $(1,2)$; (2) between endemic or non-endemic region (1, 2); (3) between regions inhabited by $D$. reticulatus in different time-new expansion zones in western or central Poland, old endemic regions in central or north-eastern Poland (1-4 categories); (4) between northern, central and the southern areas (1-3) among both expansion zones.

All factors were fitted into a full factorial model. Beginning with the most complex model, involving all possible main effects and interactions, those combinations not contributing significantly to explaining variation in the data were eliminated stepwise (backward selection procedure), beginning with the highest-level interaction [50]. A minimum sufficient model was then obtained, for which the likelihood ratio of $\chi^{2}$ was not significant, indicating that the model was sufficient in explaining the data.

\section{New nucleotide sequences}

New nucleotide sequences have been deposited in GenBank with the accession numbers KT272401 for $18 \mathrm{~S}$ rRNA of B. canis and KT277489 for gltA of R. raoulti.

\section{Ethical approval}

The study was approved by the National Science Center (NCN).

\section{Results}

\section{Prevalence of pathogens in questing D. reticulatus}

Of the total 2585 examined ticks, 1197 (46.3\%) were infected with at least one pathogen. Overall, the prevalence of detected pathogens was $4.18 \%$ (108/2585) for Babesia spp., 44.10 \% (1140/2585) for Rickettsia spp., 
Table 2 Prevalence of B. canis and R. raoulti in D. reticulatus collected in areas covered by the Eastern and the Western population

\begin{tabular}{|c|c|c|c|c|c|c|c|c|c|c|c|}
\hline Population & $\begin{array}{l}\text { B. canis } \\
\text { positive/ } \\
\text { total (\%) }\end{array}$ & $\begin{array}{l}\text { R. raoulti } \\
\text { positive/ } \\
\text { total (\%) }\end{array}$ & Endemicity & $\begin{array}{l}\text { B. canis } \\
\text { positive/ } \\
\text { total (\%) }\end{array}$ & $\begin{array}{l}\text { R. raoulti } \\
\text { positive/ } \\
\text { total (\%) }\end{array}$ & $\begin{array}{l}\text { Time of } \\
\text { inhabitation }\end{array}$ & $\begin{array}{l}\text { B. canis } \\
\text { positive/ } \\
\text { total (\%) }\end{array}$ & $\begin{array}{l}\text { R. raoulti } \\
\text { positive/ } \\
\text { total (\%) }\end{array}$ & $\begin{array}{l}\text { Area of expansion } \\
\text { zone }\end{array}$ & B. canis & R. raoulti \\
\hline \multirow[t]{5}{*}{$\begin{array}{l}\text { Eastern } \\
\text { population }\end{array}$} & \multirow[t]{5}{*}{ 108/1993 (5.42) } & \multirow[t]{5}{*}{$832 / 1993$ (41.75) } & \multirow[t]{2}{*}{ endemic regions } & \multirow[t]{2}{*}{ 69/1198 (5.76) } & \multirow[t]{2}{*}{$451 / 1198(37.65)$} & $\begin{array}{l}\text { Warmińsko- } \\
\text { Mazurskie }\end{array}$ & $11 / 474(2.32)$ & 162/474 (34.18) & & \multirow[t]{2}{*}{$\begin{array}{l}\text { positive/ } \\
\text { total (\%) }\end{array}$} & \multirow[t]{2}{*}{$\begin{array}{l}\text { positive/ } \\
\text { total (\%) }\end{array}$} \\
\hline & & & & & & Masovian & $58 / 724(8.01)$ & 289/724 (39.92) & & & \\
\hline & & & \multirow{3}{*}{$\begin{array}{l}\text { non-endemic } \\
\text { regions (expansion } \\
\text { zones) }\end{array}$} & \multirow[t]{3}{*}{$39 / 1387(2.81)$} & \multirow[t]{3}{*}{ 689/1387 (49.68) } & \multirow{3}{*}{$\begin{array}{l}\text { west of the } \\
\text { Vistula River }\end{array}$} & \multirow[t]{3}{*}{ 39/795 (4.91) } & \multirow[t]{3}{*}{$381 / 795$ (47.92) } & northern & 1/148 (0.68) & $37 / 148(25.0)$ \\
\hline & & & & & & & & & central & $5 / 424(1.18)$ & 236/424 (55.66) \\
\hline & & & & & & & & & southern & $33 / 223(14.80)$ & $108 / 223(48.43)$ \\
\hline \multirow{3}{*}{$\begin{array}{l}\text { Western } \\
\text { population }\end{array}$} & \multirow[t]{3}{*}{ 0/592 (0) } & \multirow[t]{3}{*}{ 308/592 (52.03) } & & & & \multirow{3}{*}{$\begin{array}{l}\text { western } \\
\text { Poland }\end{array}$} & \multirow[t]{3}{*}{ 0/592 (0) } & \multirow[t]{3}{*}{$308 / 592(52.03)$} & northern & 0/47 (0) & $33 / 47(70.21)$ \\
\hline & & & & & & & & & central & 0/432 (0) & $212 / 432(49.07)$ \\
\hline & & & & & & & & & southern & 0/113 (0) & 63/113 (55.75) \\
\hline Total & & & & & & & $\begin{array}{l}108 / 2585 \\
(4.18)\end{array}$ & $\begin{array}{l}1140 / 2585 \\
(44.10)\end{array}$ & & & \\
\hline
\end{tabular}


$0.09 \%$ (1/1107) for Borrelia afzelii and $7.6 \%$ (7/92) for TBEV. The summary of results of all molecular analysis is provided in Table 2.

\section{Genotyping and diversity of pathogens}

The $550 \mathrm{bp}$ fragment of the 18S rRNA gene of Babesia spp. was detected in 108 isolates from ticks collected from the Eastern population. Fifty three PCR products of reaction with Bab GR2/GF2 primers and 5 with Piro A/Piro B primers were sequenced. Thirty two sequences were derived from ticks collected in the expansion zone in central Poland (west of the Vistula River), and 23 and 3 in the endemic regions of Masovian and WarmińskoMazurskie voivodeships, respectively. Forty sequences derived from the reaction with Bab GR2/GF2 primers were identical and showed $99.81 \%(520 / 521)$ similarity to B. canis (GenBank: FJ209024, AY072926, EU622793, AY962187) derived from dogs in Croatia [51], Italy [52], Poland (B. canis isolate 2) [53] and from southwestern Siberia [54]. In a further 14 identical sequences, two unresolved positions were detected at position $610(\mathrm{~A} \leftrightarrow \mathrm{G})$ and position $611(\mathrm{~A} \leftrightarrow \mathrm{G})$ of the complete 18S rRNAgene (AY072926), indicating the presence of different alleles of $B$. canis. One isolate from a male tick collected in Łuknajno (endemic regions of Warmińsko-Mazurskie Voivodeship, north-eastern Poland) was identified as B. microti showing $99.81 \%(512 / 513)$ similarity to $B$. microti clone Omsk-vole110 (GenBank: KC581934) derived from a bank vole in Western Siberia in Russia [55]. This is a genetic variant of the nonpathogenic Babesia microti Munich strain.

Of the 1140 amplicons of Rickettsia spp., 127 were sequenced and analyzed: 17 and 8 were obtained from ticks collected in endemic regions of Masovian and WarmińskoMazurskie voivodeships, respectively, 23 and 79 (4 sites) from the expansion zones of the Eastern and Western populations, respectively. All obtained sequences were identical and showed $99.86 \%$ (717/718) similarity to $R$. raoulti Krasnoobsk strain (GenBank: KM288483).

Although bands of the correct size for Borrelia fla gene fragment (about $600 \mathrm{bp}$ ) were obtained for ten DNA isolates, only one PCR product was successfully sequenced. Therefore, only one female tick collected in Kury (endemic region, Masovian Voivodeship) was considered as positive. The sequence obtained showed $99.81 \%(554 / 555)$ similarity to B. afzelii genotype (GenBank: DQ016619).

\section{Co-infections in questing ticks}

In total, co-infections with two pathogens were identified in $59(2.3 \%)$ ticks. However, prevalence of coinfections exceeded $3 \%$ (59/1993) among the Eastern tick population. Co-infections with three or more species of pathogens were not detected. The majority of coinfections (53 ticks) were with $R$. raoulti and B. canis.
Double infections were more common in the endemic region of Masovian Voiodeship (29 ticks) than in the Warmińsko-Mazurskie (3 ticks). In the expansion zone west of the Vistula River, 21 ticks were co-infected with $B$. canis and $R$. raoulti. Additionally, six ticks from the endemic regions of the Masovian Voivodeship were infected with $R$, raoulti and TBEV.

\section{Comparison of B. canis infection in questing ticks from different regions}

Babesia canis DNA was found only in ticks from the Eastern D. reticulatus population $(108 / 1993=5.42 \%)$. All 592 isolates from the Western tick population were negative $\left(\chi^{2}=35.38, d f=1, p<0.001\right)$. The differences in prevalence of $B$. canis between regions among the Eastern population inhabited in different years were also significant $\left(x^{2}=71.51, d f=3, p<0.001\right)$. The highest prevalence was found in ticks from the endemic regions of the Masovian Voivodeship in central Poland $(58 / 724=8.01 \%)$ and the lowest in the endemic regions of Warmińsko-Mazurskie Voivodeship in north-eastern Poland $(11 / 474=2.32 \%)$. In the expansion zone west of the Vistula River 4.91 \% (39/ 795) of ticks were infected.

Interestingly, in the expansion zone west of the Vistula River, the prevalence of Babesia spp. changed significantly in a north-to-southerly direction $\left(\chi^{2}=65,71\right.$, $d f=2, p<0.001)$. In northern and central areas the prevalence of Babesia spp. was relatively low- $0.68 \%$ $(1 / 148)$ and $1.18 \%(5 / 424)$, respectively. In the southern region the number of positive ticks was unexpectedly high $(33 / 233)$, resulting in the highest prevalence recorded (14.8\%).

\section{Comparison of Rickettsia spp. infection in questing ticks from different regions}

In contrast to $B$. canis, the prevalence of $R$. raoulti infection was similar in the Western and the Eastern $D$. reticulatus populations: $52.03 \%$ (308/592) and $41.75 \%$ (832/1993), respectively (NS).

Prevalence of $R$. raoulti in ticks in the endemic regions, east of the Vistula River was similar (37.65 \%; $451 / 1198)$ to prevalence in the non-endemic regions located between the Vistula River and the western border of the country $(49.68 \%$; 689/1387) (NS).

Interestingly, there was a marked increasing trend in the prevalence along an east-west geographic axis (Fig. 2). The highest prevalence was found, as mentioned above, in western Poland (western expansion zone) $(52.03 \%)$ and this declined eastwards. Prevalence was $47.92 \%(381 / 795)$ in the expansion zone west of the Vistula River; $39.92 \%$ (289/724) in the endemic region of the Masovian Voivodeship and $34.18 \%(162 / 474)$ in the endemic region of the Warmińsko-Mazurskie Voivodeship in NE Poland. The differences in Rickettsia prevalence 


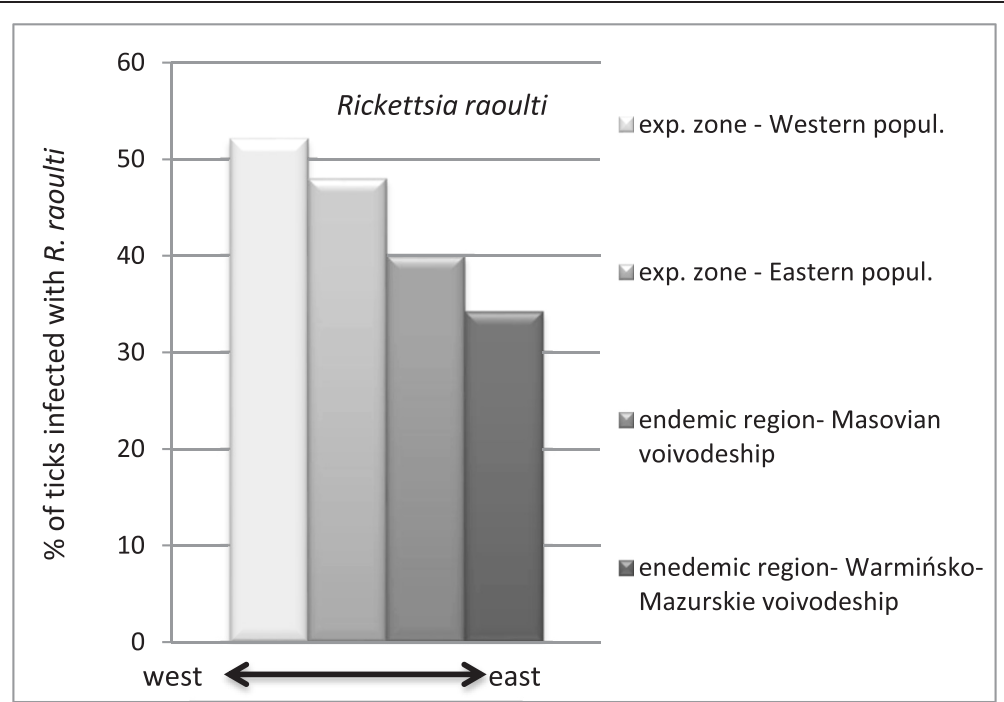

Fig. 2 Prevalence of $R$. raoulti in D. reticulatus from the expansion zones (western Poland and west of the Vistula River) and from endemic regions (central and north-eastern Poland)

between the four geographical regions were significant $\left(\chi^{2}=44.21, d f=3, p<0.001\right)$ (Fig. 2).

As with $B$. canis, prevalence of $R$. raoulti differed significantly in a north-to-south direction in both expansion zones (in western Poland and west of the Vistula River) $\left(\chi^{2}=17.44, d f=2, p<0.001\right)$ but in western Poland the trend was reversed. The highest prevalence was found in northern districts of the western expansion zone - $70.21 \%$ (33/47) with lower values for central and southern areas: $49.07 \%(212 / 432)$ and $55.75 \%(63 / 113)$, respectively. In the expansion zone in central Poland (west of the Vistula River), prevalence of $R$. raoulti in central $(236 / 424=55.66 \%)$ and southern $(108 / 223=48.43 \%)$ areas was about twice as high as in the northern districts $(37 / 148=25 \%)$.

\section{Comparison of parasite range between different tick populations}

The number of pathogen species vectored by $D$. reticulatus was lower in the Western tick population (only $R$. raoulti was found) in comparison to the Eastern population (B. canis, B. microti, B. afzelii, R. raoulti). Additionally, TBEV was detected in the Eastern tick population, although we made no attempt to identify this pathogen in ticks from the Western population. The range of vectored pathogens was similar in endemic regions east of the Vistula River (Masovian and Warmińsko-Mazurskie voivodeships) and in the adjacent central expansion zone (west of Vistula River).

Interestingly, there were marked differences in the prevalence of pathogens between the different sampling sites in the recently established expansion zones, especially regarding $B$. canis (0.68-14.8\%) in central and $R$. raoulti (25-70.2\%) in both western and central expansion zones.

\section{Discussion}

The present study focused on pathogens vectored by $D$. reticulatus ticks in endemic regions and zones of expansion in Poland. Almost every second tick was infected by TBP's (46.3\%), yet spatial diversity in prevalence of TBP's was noted between ticks collected from the two isolated tick populations and among sampling sites in the expansion zones. It is highly likely that those two tick populations are of different origin. The tick population in eastern Poland is well known as a constituent of the Eastern macro region of $D$. reticulatus [12, 21]. New foci of this tick in the expansion zone in central Poland are a likely extension of this population and continuous with it. On the other hand, it is likely that ticks from western Poland originated from the adjacent population settled in eastern Germany [56, 57]. Because of the likely different origin of these tick populations, some differences in TBP's prevalence as well as pathogen genetic diversity might be expected.

We found that differences in the prevalence of $B$. canis were the most obvious. All positive ticks were collected in eastern and central Poland (Eastern tick population) while all ticks from the West of the country were negative for this pathogen. The prevalence of B. canis in our study $(4.18 \%)$ as detected in questing adult ticks, is one of the highest on record. In general the prevalence of $B$. canis is higher in the Eastern macro region in 
comparison with the Western European one. In neighboring countries east of Poland prevalence of B. canis has been reported to vary from $0 \%$ to $3.6 \%$. In a recent study conducted by Karbowiak et al. [58] 6 out of 205 (3.14 \%) ticks collected in the Chernobyl exclusion zone in the Ukraine were positive, while in relatively close locations in southern Belarus, Reye et al. [32] did not detect any positive ticks among 142 questing adults and 124 ticks collected from animals. In ticks collected in Western Siberia in Russia B. canis was found in $3.6 \%$ of D. reticulatus [55]. In the West European macro region the prevalence of $B$. canis has been reported to vary in the range 0 $1.64 \%$. Reports from France (endemic region for canine babesiosis $[1,59,60]$ are scarce but in a study conducted by Bonnet et al. [31] no B. canis DNA was found in 74 ticks collected in eastern France, while in western Germany prevalence was estimated at $2.5 \%$ [61]. This region, as well as territory in northern Spain, Belgium and Netherlands has been inhabited by $D$. reticulatus in the last decades [62]. In these countries Babesia canis has been identified in $1 \%$ [63], $0 \%$ [64] and $1.64 \%$ [65] of marsh ticks, respectively. Exceptionally high prevalence of B. canis infection in questing D. reticulatus ticks (83\%, 19/23) was reported by Schaarschmidt et al. [66] in the Swiss Midlands, another 'expansion zone' of marsh ticks. In this last study, the presence of B. canis was confirmed in 9 samples (39.1\%) by sequencing the $18 \mathrm{~S}$ rRNA gene. In this region the first outbreaks of canine babesiosis were described at the beginning of the $\mathrm{XXI}^{\text {th }}$ century. The authors attributed such a high prevalence to the probable formation of microfoci of ticks. Such a focus, with an unexpectedly high prevalence (14.8\%), was also detected in our study among ticks collected in southern areas of the expansion zone in central Poland. The reasons for this phenomenon are not clear and need further investigation.

In our study, differences in the prevalence of $B$. canis in ticks were associated with the time of settlement of tick populations in particular areas. The differences in prevalence of B. canis in endemic regions and in the expansion zone that we recorded, correspond well with the results of a recent study conducted by Kubelová et al. [67] in Slovakia, where overall prevalence of B. canis was $3.2 \%$, and where prevalence of $B$. canis in D. reticulatus varied significantly between east (14.7\%), southwest $(2.3 \%)$ and west regions of the country $(0 \%)$. The authors hypothesized that this geo-spatial shift in prevalence of B. canis was a consequence of the spread of $D$. reticulatus from the south-east in a north-western direction. Svehlová et al. [68] confirmed a similar prevalence of B. canis in this tick species from southwestern Slovakia (1.8 \%). This pattern raises questions about the possible mechanisms of emergence and settlement of canine babesiosis in non-endemic territories. One possibility is that uninfected ticks spread and survive in the newly colonized areas more effectively than carriers of B. canis. In order to fully understand the pattern of emergence of canine babesiosis, complex investigations are required of the interactions between the protozoan parasites, their vectors and the wild animals that may serve as reservoir hosts.

Differences in prevalence of $R$. raoulti between the two Polish tick populations were far less pronounced (52 versus $42 \%)$. Although the two expansion zones are separated by a $260-300 \mathrm{~km}$ wide interval, the infection rates in zones were very much alike (52 versus $48 \%$ ). However, the pattern of north-to-south differences in prevalence of $R$. raoulti was reversed in these two zones. Also a difference in the prevalence of $R$. raoulti was evident in a westto-east direction, with the highest infection rate in the Western population (52\%). This is consistent with studies conducted in area of Germany, west of Poland, where prevalence of this species is higher than in eastern and southeastern European countries. In southern Germany about $30 \%$ of $D$. reticulatus have been found to be positive [69, 70], but increasing to $43 \%$ and $67 \%$ in the west (Saarland) and the east of the country (Saxony), respectively [70]. In Slovakia $26 \%$ of ticks collected from vegetation were positive [71] and in Belarus $22 \%$ [32]. The lowest prevalence (5\%) has been reported in the United Kingdom - an isolated island [36]. The range of prevalence of $R$. raoulti found in our study reflects well the results obtained by other authors in Poland. In the Lubelskie Voivodeship in eastern Poland 53 \% (280/528) of $D$. reticulates were positive [72]. In north-eastern Poland Stańczak [73] found $41 \%$ (116/285) of D. reticulatus ticks to be infected and Chmielewski et al. [74] detected $R$. raoulti in $57 \%(34 / 60)$ ticks from Białowieża Primeval Forest National Park.

Differences in the prevalence of $B$. canis and $R$. raoulti can be explained by their dissimilar relationships with the vector. Babesia spp. have a complex life cycle involving ticks and vertebrate hosts. This protozoa undergoes sexual development in ticks and only gametocytes can survive in the midgut of the tick during the blood meal. Despite adaptive mechanisms, Babesia spp. affect the fitness of ticks [75]. In contrast, Rickettsia spp. are claimed to be possible endosymbionts of ticks with a commensal or even mutualistic association with their hosts [76, 77]. However, the ability of highly pathogenic Rickettsia rickettsii to reduce fitness and fertility of $D$. andersoni was also documented [78]. D. reticulatus ticks are competent reservoirs and vectors of $R$. raoulti although to-date no vertebrate hosts have been recognized as reservoir. The high prevalence of $R$. raoulti may be facilitated through transovarial and transstadial transmission which has been clearly demonstrated [79]. Given that the genetic diversity of these pathogens is known to be limited, confirmation of the primary origin of Polish Eastern and Western tick populations needs further investigation, and genotyping individuals 
from both regions of the $D$. reticulatus range, Western European or Eastern may help to resolve the issue.

Two species of Babesia were found in the current study: B. canis and B. microti. B. microti was detected only in one male collected in Warmińsko-Mazurskie Voivodeship, and this is the first report of this species in $D$. reticulatus from north-eastern Poland. Interestingly, Wójcik-Fatla et al. [80] found B. microti to be dominant over $B$. canis (2.1\% versus $0.7 \%$ ) in D. reticulatus ticks collected in the Lubelskie Voivodeship (eastern Poland). Some of the sequences detected were homologous to a genetic variant of the $B$. microti Munich strain, as in our study. High prevalence of this genotype (30-36 \%) was observed also by Siński et al. [81] in Microtus spp. captured in the same region (Mazury Lake District, Warmińsko-Mazurskie Voivodeship). Microtus spp. voles are the main hosts for instars of $D$. reticulatus [82-84], and therefore trace amounts of B. microti DNA may be detected in this tick species. Interestingly, B. canis has low genetic variability in $18 \mathrm{~S}$ rDNA, given that the same genotype was found in Croatia, Italy, Poland and southeastern Siberia. Elsewhere, $D$. reticulatus have been found to be infected also with other Babesia species [63, 65], however their role in the transmission of these pathogens to susceptible hosts needs further investigation.

Bacteria of the genus Rickettsia were the most prevalent pathogens found in D. reticulatus in all sampled regions with an overall prevalence $44.10 \%$. All 127 sequences derived from ticks collected in both expansion zones and endemic regions in Masovian and Warmińsko-Mazurskie Voivodeships were identical and homologous to $R$. raoulti. This species was detected for the first time by Rydkina et al. [85] in Russia and it was described by Mediannikov et al. [86] as a novel species. Subsequently this intracellular bacterium has been classified in the spotted fever group (SFG) of Rickettsia. Together with $R$. slovaca and R. sibirica, $R$. raoulti is thought to be responsible for tick-borne lymphadenopathy (TIBOLA), a syndrome that is manifested mainly by eschar around the tick attachment sites and enlargement of the nearest lymph nodes. Cases of TIBOLA caused by $R$. raoulti have been reported from Spain [87], France [86, 88], Germany [89], Hungary [29] and Poland [90]. Földvári et al. [29] connected 6 cases of TIBOLA in humans to the bites of $D$. reticulatus, having amplified $R$. raoulti DNA from 5 females and 1 male $D$. reticulatus collected from patients with this syndrome.

Evidence for the pathogenicity of $R$. raoulti for animals is so far lacking. Moreover, only $2.8 \%$ of dogs from Germany, examined with the micro-IFA test, have been found to be seropositive for $R$. raoulti [91] in contrast to $R$. helvetica (66\%). Other tick species have been found also to harbour $R$. raoulti, e.g., Rhipicephalus pumilio, $D$. nutalli [85], D. marginatus [92], I. ricinus [74]. However,
D. reticulatus appears to be the main vector involved in transmission of the bacteria in Poland and other countries where it occurs, as reflected in the high prevalence of $R$. raoulti in our and other studies.

The potential role of $D$. reticulatus in the maintenance and circulation of TBEV and a link with cattle as reservoir hosts has been demonstrated in recent studies [38, 39], including ours. The prevalence of TBEV estimated in our study $(7.6 \%)$ is consistent with the results obtained by Wójcik-Fatla et al. [38] in tick samples from the Lubelskie Voivodeship (10.8 \%). In a study conducted by Biernat et al. [39] the prevalence of TBEV varied across northeastern and central Poland (0.99-12.5 \%) and it is known to vary also between susceptible tick species. For example, prevalence of TBEV in $D$. reticulatus may be up to 10 times higher than in I. ricinus $(7-11 \%$ versus $0-1.2 \%$; $[38,93])$. Cattle have been shown to be competent hosts for $D$. reticulatus and the dominance of this tick over I. ricinus on bovine hosts in endemic regions has been reported recently [28]. Grazing cattle may play a dual role; they serve as an easily available source of blood meal compared to wild animals thus supporting the expansion of $D$. reticulatus and act as a reservoir for the tick-borne encephalitis virus (TBEV). Transmission of TBEV to cattle may be followed by transfer of this virus to humans via nonpasteurized milk or other dairy products from infected animals (mainly goats, sheep and cows) [94]. Milk-borne TBE outbreaks or single cases have been reported from Eastern Europe, Austria and Germany [95].

Low prevalence of $B$. burgdorferi s.l. in D. reticulatus has been reported in many earlier studies including our own (0.09 \%): 0 \% in Germany [35], United Kingdom [36] and Serbia [33], $0.6 \%$ in the Lubelskie Voivodeship in Poland [96], $1.5 \%$ in France [31], $2.7 \%$ in Belarus [32] and Borrelia afzeli has been the most often detected genotype of the B. burgdorferi s.l. complex, as also in our study. However, in contrast to these low overall prevalence rates, this genotype has been reported with a much higher prevalence in engorged nymphs of $D$. reticulatus removed from Microtus spp., which are known to be reservoir host for B. afzeli (Bajer unpublished). An explanation for these contrasting prevalence rates can be found in reports that indicate a rapid drop in the infection rate with Borrelia spp. in D. reticulatus shortly after feeding [97]. Extracts from the midguts of D. reticulatus have been shown to inhibit the growth of Borrelia spirochetes in vitro [98] and an active immune response against Borrelia bacteria, leading to lysis of the spirochaetes, has been demonstrated in D. variabilis [99]. Based on these findings, it is likely that the fall in the prevalence of $B$. burgdorferi s.l. in adult $D$. reticulatus is a consequence of the inactivation of bacteria by the immune system of the ticks. Therefore $D$. reticulatus are not competent vectors for the Borrelia burgdorferi s.l. 
complex [100] and it is unlikely that this tick is involved in transmission and epidemiology of Lyme boreliosis.

\section{Conclusions}

Prevalence of TBP's transmitted by D. reticulatus in Poland depends on the region of study. The region with the highest probability of transmission of $B$. canis, in both the endemic region and expansion zone, is the Masovian Voivodeship. Due to the high prevalence of $R$. raoulti, $B$. canis and TBEV, the endemic regions of the Masovian Voivodeship are at the greatest risk of diseases caused by TBP's of medical and veterinary importance. $R$. raoulti is the most prevalent pathogen harbored by $D$. reticulatus and may be the main cause of TIBOLA in Poland.

\section{Competing interests}

The authors declare that they have no competing interests.

\section{Authors' contributions}

The study was designed and performed by EJM. RWF participated in molecular studies on Rickettsia spp. AP and MR supervised the molecular studies on TBEV. EJM and AB performed field studies and drafted the manuscript. All authors read and approved the final version of the manuscript.

\section{Acknowledgements}

The study was supported by the National Science Center (NCN) grants: OPUS 2011/03/B/NZ8/02212 and Sonata Bis 2014/14/E/NZ7/00153.

\section{Author details}

'Department of Parasitology, Institute of Zoology, Faculty of Biology, University of Warsaw, 1 Miecznikowa Street, 02-096 Warsaw, Poland. 2Department of Immunopathology of Infectious and Parasitic Diseases, Medical University of Warsaw, 3c Pawińskiego Street, 02-106 Warsaw, Poland.

Received: 23 July 2015 Accepted: 16 September 2015

Published online: 24 September 2015

\section{References}

1. Bourdoiseau G. Canine babesiosis in France. Vet Parasitol. 2006;138:118-25.

2. Beugnet $F$, Marie JL. Emerging arthropod-borne diseases of companion animals in Europe. Vet Parasitol. 2009;163:298-305.

3. Iori A, Gabrielli S, Calderini P, Moretti A, Pietrobelli M, Tampierie MP, et al. Tick reservoirs for piroplasms in central and northern Italy. Vet Parasitol. 2010;170:291-6.

4. Zygner W, Gójska O, Rapacka G, Jaros D, Wedrychowicz H. Hematological changes during the course of canine babesiosis caused by large Babesia in domestic dogs in Warsaw (Poland). Vet Parasitol. 2007;145:146-5.

5. Welc-Falęciak R, Rodo A, Siński E, Bajer A. Babesia canis and other tick-borne infections in dogs in Central Poland. Vet Parasitol. 2009:166:191-8.

6. Bajer A, Mierzejewska EJ, Rodo A, Welc-Falęciak R. The risk of vector-borne infections in sled dogs associated with existing and new endemic areas in Poland. Part 2: Occurrence and control of babesiosis in a sled dog kennel during a 13-year-long period. Vet Parasitol. 2014;202:234-40.

7. Losson B, Mollet JJ, Avez F, Malaise F, Mignon B. Description de trois cas autochtones de Babésiose canine (Babesia canis) en Belgique. Ann Med Vet. 1999;143:119-24.

8. Matjila TP, Nijhof AM, Taoufik A, Houwers D, Teske E, Penzhorn BL, et al. Autochthonous canine babesiosis in The Netherlands. Vet Parasitol. 2005;131:23-9.

9. Lachmajer J. Stan badań nad pasożytniczymi Arthropoda w Polsce. Wiad Parazytol. 1963;9:359-69.

10. Szymański S. New foci of Dermacentor reticulatus (Fabricius, 1794) in Poland. Wiad Parazytol. 1977;23:35-7.

11. Szymański S. Distribution of the tick Dermacentor reticulatus (Fabricius, 1794) (Ixodidae) in Poland. Acta Parasitol Polonica. 1986;31:143-54.
12. Karbowiak G. The occurrence of the Dermacentor reticulatus tick - its expansion to new areas and possible causes. Ann Parasitol. 2014;60:6037-47.

13. Immler RM. Untersuchungen zur Biologie und Oekologie der Zecke Dermacentor reticulatus (Fabricius, 1794) (Ixodidae) in einem endemischen Vorkommensgebiet. Mitt Schweiz Ent Ges. 1973;46:2-70.

14. Kolonin GV. Mirovoe rasprostranenie iksodovykh kleshchei. Rody Dermacentor, Anocentor, Cosmiomma, Dermacentonomma, Nosomma, Rhipicentor, Rhipicephalus, Boophilus, Margaropus Anomalohimalaya. Izd. Nauka, Moskva; 1984

15. Siuda K. Kleszcze Polski (Acari: Ixodida). Systematyka i Rozmieszczenie część II. (Ticks (Acari: Ixodida) of Poland. Part II Taxonomy and Distribution) Polskie Towarzystwo Parazytologiczne, Warszawa; 1993.

16. Sobczyk AS, Kotomski G, Gorski P, Wedrychowicz H. Usefulness of touchdown PCR assay for the diagnosis of atypical cases of Babesia canis canis infections in dogs. Bull-Vet Inst Pulawy. 2005:49:407.

17. Zygner W, Wędrychowicz $\mathrm{H}$. Occurrence of hard ticks in dogs from Warsaw area. Ann Agric Environ Med. 2006;13:355-9.

18. Zygner W, Górski P, Wędrychowicz H. New localities of Dermacentor reticulatus tick (vector of Babesia canis canis) in central and eastern Poland. Pol J Vet Sci. 2009;12:549-55.

19. Supergan M, Karbowiak $G$. The estimation scale of endangerment with tick attacks on recreational towns areas. Przegl Epidemiol. 2009;63:67-71.

20. Karbowiak G, Kiewra D. New locations of Dermacentor reticulatus ticks in Western Poland: the first evidence of the merge in $D$. reticulatus occurrence areas? Wiad Parazytol. 2010;56:333-6.

21. Nowak M. Discovery of Dermacentor reticulatus (Acari: Amblyommidae) populations in the Lubuskie Province (Western Poland). Exp Appl Acarol. 2011;54:191-7

22. Kiewra D, Czulowska A. Evidence for an increased distribution range of Dermacentor reticulatus in south-west Poland. Exp Appl Acarol. 2013;59:501-6.

23. Mierzejewska EJ, Estrada- Peña A, Alsarraf M, Kowalec M, Bajer A. Mapping of tick Dermacentor reticulatus expansion in Poland in 2012-2014. Ticks Tickborne Dis. 2015; in press.

24. Hillyard PD. Ticks of North-West Europe. London: The Natural History Museum; 1996. p. 116-8.

25. Nowak-Chmura M, Siuda K. Ticks of Poland. Review of contemporary issues and latest research. Ann Parasitol. 2012;58:125-55.

26. Guglielmone AA, Robbins RG, Apanaskevich DA, Petney TN, Estrada-Peña A, Horak I. The hard ticks of the world. Dordrecht: Springer; 2014. p. 635.

27. Karbowiak G, Demiaszkiewicz AW, Pyziel AM, Wita I, Moskwa B, Werszko J, et al. The parasitic fauna of the European bison (Bison bonasus) (Linnaeus, 1758) and their impact on the conservation. Part 1. The summarising list of parasites noted. Acta Parasitol. 2014:59:363-71.

28. Mierzejewska EJ, Welc-Faleciak R, Karbowiak G, Kowalec M, Behnke JM, Bajer A. Dominance of Dermacentor reticulatus over Ixodes ricinus (Ixodidae) on livestock, companion animals and wild ruminants in eastern and central Poland. Exp Appl Acarol. 2015;66:83-101.

29. Földvári G, Rigó K, Lakos A. Transmission of Rickettsia slovaca and Rickettsia raoultii by male Dermacentor marginatus and Dermacentor reticulatus ticks to humans. Diagn Microbiol Infect Dis. 2013;76:387-9.

30. Lledó L, Gegúndez MI, Giménez-Pardo C, Álamo R, Fernández-Soto P, Nuncio MS, et al. A seventeen-year epidemiological surveillance study of Borrelia burgdorferi infections in two provinces of northern Spain. Int J Environ Res Public Health. 2014;11:1661-72.

31. Bonnet S, de la Fuente J, Nicollet P, Liu X, Madani N, Blanchard B, et al. Prevalence of tick-borne pathogens in adult Dermacentor spp. ticks from nine collection sites in France. Vector Borne Zoonotic Dis. 2013:13:226-36.

32. Reye AL, Stegniy V, Mishaeva NP, Velhin S, Hübschen JM, Ignatyev G, et al. Prevalence of tick-borne pathogens in Ixodes ricinus and Dermacentor reticulatus ticks from different geographical locations in Belarus. PLoS One. 2013;8:e54476

33. Tomanović S, Chochlakis D, Radulović Z, Milutinović M, Cakić S, Mihaljica D, et al. Analysis of pathogen co-occurrence in host-seeking adult hard ticks from Serbia. Exp Appl Acarol. 2013;59:367-76.

34. Wójcik-Fatla A, Zając V, Sawczyn A, Cisak E, Sroka J, Dutkiewicz J. Occurrence of Francisella spp. in Dermacentor reticulatus and Ixodes ricinus ticks collected in eastern Poland. Ticks Tick Borne Dis. 2015;6:253-7.

35. Richter D, Kohn C, Matuschka FR. Absence of Borrelia spp., Candidatus Neoehrlichia mikurensis, and Anaplasma phagocytophilum in questing adult Dermacentor reticulatus ticks. Parasitol Res. 2013;112:107-11. 
36. Tijsse-Klasen E, Hansford KM, Jahfari S, Phipps P, Sprong H, Medlock JM. Spotted fever group rickettsiae in Dermacentor reticulatus and Haemaphysalis punctata ticks in the UK. Parasit Vectors. 2013;19(6):212.

37. Szekeres S, Claudia Coipan E, Rigó K, Majoros G, Jahfari S, Sprong H, et al. Candidatus Neoehrlichia mikurensis and Anaplasma phagocytophilum in natural rodent and tick communities in Southern Hungary. Ticks Tick Borne Dis. 2015;6:111-6.

38. Wójcik-Fatla A, Cisak E, Zając V, Zwoliński J, Dutkiewicz J. Prevalence of tick-borne encephalitis virus in Ixodes ricinus and Dermacentor reticulatus ticks collected from the Lublin region (eastern Poland). Ticks Tick Borne Dis. 2011;2:16-9.

39. Biernat B, Karbowiak G, Werszko J, Stańczak J. Prevalence of tick-borne encephalitis virus (TBEV) RNA in Dermacentor reticulatus ticks from natural and urban environment. Poland Exp Appl Acarol. 2014;64:543-51.

40. Weissenböck H, Suchy A, Holzmann H. Tick-borne encephalitis in dogs: neuropathological findings and distribution of antigen. Acta Neuropathol. 1998:95:361-6.

41. Bajer A, Rodo A, Bednarska M, Mierzejewska E, Welc-Falęciak R. Babesia canis and tick-borne encephalitis virus (TBEV) co-infection in a sled dog. Ann Agric Environ Med. 2013;20:426-30.

42. Roux V, Rydkina E, Eremeeva M, Raoult D. Citrate synthase gene comparison, a new tool for phylogenetic analysis, and its application for the rickettsiae. Int J Syst Bacteriol. 1997:47:252-61.

43. Bonnet S, Jouglin M, L'Hostis M, Chauvin A. Babesia sp. EU1 from roe deer and transmission within Ixodes ricinus. Emerg Infect Dis. 2007;13:1208-10.

44. Bonnet S, Jouglin M, Malandrin L, Becker C, Agoulon A, L'Hostis M, et al. Transstadial and transovarial persistence of Babesia divergens DNA in Ixodes ricinusticks fed on infected blood in a new skin-feeding technique. Parasitology. 2007;134:197-207.

45. Armstrong PM, Katavolos P, Caporale DA, Smith RP, Spielman A, Telford SR Diversity of Babesia infecting deer ticks (Ixodes dammini). Am J Trop Med Hyg. 1998;58:739-42nnn

46. Welc-Faleciak R, Bajer A, Bednarska M, Paziewska A, Siński E. Long term monitoring of Babesia microti infection in BALB/C mice using nested PCR. Ann Agric Environ Med. 2007;14:287-90.

47. Welc-Falęciak R, Kowalec M, Karbowiak G, Bajer A, Behnke JM, Siński E. Rickettsiaceae and Anaplasmataceae infections in Ixodes ricinus ticks from urban and natural forested areas of Poland. Parasit Vectors. 2014;24(7):121.

48. Picken MM, Picken RN, Han D, Cheng Y, Strle F. Single-tube nested polymerase chain reaction assay based on Flagellin gene sequences for detection of Borrelia burgdorferi sensu lato. Eur J Clin Microbiol Infect Dis. 1996;15:489-98.

49. Melik W, Nilsson AS, Johansson M. Detection strategies of tick-borne encephalitis virus in Swedish Ixodes ricinus reveal evolutionary characteristics of emerging tick-borne flaviviruses. Arch Virol. 2007;152:1027-34

50. Bajer A, Bednarska M, Pawełczyk A, Behnke JM, Gilbert FS, Sinski E. Prevalence and abundance of Cryptosporidium parvum and Giardia spp. in wild rural rodents from the Mazury Lake District region of Poland. Parasitology. 2002;125:21-34.

51. Beck R, Vojta L, Mrljak V, Marinculić A, Beck A, Zivicnjak T, et al. Diversity of Babesia and Theileria species in symptomatic and asymptomatic dogs in Croatia. Int J Parasitol. 2009:39:843-8.

52. Cacciò SM, Antunovic B, Moretti A, Mangili V, Marinculic A, Baric RR, et al Molecular characterisation of Babesia canis canis and Babesia canis vogeli from naturally infected European dogs. Vet Parasitol. 2002;106:285-92.

53. Adaszek L, Winiarczyk S. Molecular characterization of Babesia canis canis isolates from naturally infected dogs in Poland. Vet Parasitol. 2008:152:235-41.

54. Rar VA, Maksimova TG, Zakharenko LP, Bolykhina SA, Dobrotvorsky AK, Morozova OV. Babesia DNA detection in canine blood and Dermacentor reticulatus ticks in southwestern Siberia, Russia. Vector Borne Zoonotic Dis. 2005;5:285-7.

55. Rar VA, Fomenko NV, Dobrotvorsky AK, Livanova NN, Rudakova SA, Fedorov EG, et al. Tickborne pathogen detection, Western Siberia, Russia. Emerg Infect Dis. 2005;11:1708-15.

56. Dautel H, Dippel C, Oehme R, Hartelt K, Schettler E. Evidence for an increased geographical distribution of Dermacentor reticulatus in Germany and detection of Rickettsia sp. RpA4. Int J Med Microbiol. 2006;296:149-56.

57. Silaghi C, Woll D, Hamel D, Pfister K, Mahling M, Pfeffer M. Babesia spp.and Anaplasma phagocytophilum in questing ticks, ticks parasitizing rodents and the parasitized rodents - analyzing the host-pathogen-vector interface in a metropolitan area. Parasit Vectors. 2012;5(5):191.
58. Karbowiak G, Vichová B, Slivinska K, Werszko J, Didyk J, Pet'ko B, et al. The infection of questing Dermacentor reticulatus ticks with Babesia canis and Anaplasma phagocytophilum in the Chernobyl exclusion zone. Vet Parasitol. 2014;204:372-5.

59. Halos L, Lebert I, Chao I, Vourc'h G, Ducrot C, Abrial D, et al. Questionnairebased survey on distribution and clinical incidence of canine babesiosis in France. BMC Vet Res. 2013;28(9):41.

60. René-Martellet M, Chêne J, Chabanne L, Chalvet-Monfray K, Bourdoiseau G. Clinical signs, seasonal occurrence and causative agents of canine babesiosis in France: results of a multiregional study. Vet Parasitol. 2013;197:50-8.

61. Beelitz P, Schumacher S, Marholdt F, Pfister K, Silaghi C. The prevalence of Babesia canis canis in marsh ticks (Dermacentor reticulatus) in the Saarland. Berl Munch Tierarztl Wochenschr. 2012;125:168-71.

62. Halos L, Lebert I, Abrial D, Danlois F, Garzik K, Rodes D, et al. Questionnairebased survey on the distribution and incidence of canine babesiosis in countries of Western Europe. Parasite. 2014;21:13

63. García-Sanmartín J, Barandika JF, Juste RA, García-Pérez AL, Hurtado A. Distribution and molecular detection of Theileria and Babesia in questing ticks from northern Spain. Med Vet Entomol. 2008;22:318-25.

64. Cochez C, Lempereur L, Madder M, Claerebout E, Simons L, De Wilde N, et al. Foci report on indigenous Dermacentor reticulatus populations in Belgium and a preliminary study of associated babesiosis pathogens. Med Vet Entomol. 2012;26:355-8.

65. Jongejan F, Ringenier M, Putting M, Berger L, Burgers $S$, Kortekaas $R$, et al. Novel foci of Dermacentor reticulatus ticks infected with Babesia canis and Babesia caballi in the Netherlands and in Belgium. Parasit Vectors. 2015:8:232.

66. Schaarschmidt D, Gilli U, Gottstein B, Marreros N, Kuhnert P, Daeppen JA, et al. Questing Dermacentor reticulatus harbouring Babesia canis DNA associated with outbreaks of canine babesiosis in the Swiss Midlands. Ticks Tick Borne Dis. 2013:4:334-40.

67. Kubelová M, Tkadlec E, Bednár M, Roubalová E, Široký P. West-to-east differences of Babesia canis canis prevalence in Dermacentor reticulatus ticks in Slovakia. Vet Parasitol. 2011;180:191-6.

68. Svehlová A, Berthová L, Sallay B, Boldiš V, Sparagano OA, Špitalská E. Sympatric occurrence of Ixodes ricinus, Dermacentor reticulatus and Haemaphysalis concinna ticks and Rickettsia and Babesia species in Slovakia. Ticks Tick Borne Dis. 2014;5:600-5.

69. Pluta S, Hartelt K, Oehme R, Mackenstedt U, Kimmig P. Prevalence of Coxiella burnetii and Rickettsia spp. in ticks and rodents in southern Germany. Ticks Tick Borne Dis. 2010;1:145-7.

70. Silaghi C, Hamel D, Thiel C, Pfister K, Pfeffer M. Spotted fever group rickettsiae in ticks, Germany. Emerg Infect Dis. 2011;17:890-2.

71. Špitalská E, Stefanidesová K, Kocianová E, Boldiš V. Rickettsia slovaca and Rickettsia raoultii in Dermacentor marginatus and Dermacentor reticulatus ticks from Slovak Republic. Exp Appl Acarol. 2012;57:189-97.

72. Wójcik-Fatla A, Cisak E, Zając V, Sroka J, Sawczyn A, Dutkiewicz J. Study on tick-borne rickettsiae in eastern Poland. I. Prevalence in Dermacentor reticulatus (Acari: Amblyommidae). Ann Agric Environ Med. 2013;20:276-9.

73. Stańczak J. Detection of spotted fever group (SFG) rickettsiae in Dermacentor reticulatus (Acari: Ixodidae) in Poland. Int J Med Microbiol. 2006;296 Suppl 40:144-8.

74. Chmielewski T, Podsiadly E, Karbowiak G, Tylewska-Wierzbanowska S. Rickettsia spp. in ticks, Poland. Emerg Infect Dis. 2009;15:486-8.

75. Chauvin A, Moreau E, Bonnet S, Plantard O, Malandrin L. Babesia and its hosts: adaptation to long-lasting interactions as a way to achieve efficient transmission. Vet Res. 2009;40:37.

76. Perlman SJ, Hunter MS, Zchori-Fein E. The emerging diversity of Rickettsia. Proc Biol Sci. 2006;273:2097-106.

77. Taylor M, Mediannikov O, Raoult D, Greub G. Endosymbiotic bacteria associated with nematodes, ticks and amoebae. FEMS Immunol Med Microbiol. 2012:64:21-31.

78. Niebylski ML, Peacock MG, Schwan TG. Lethal effect of Rickettsia rickettsii on its tick vector (Dermacentor andersoni). Appl Environ Microbiol. 1999;65:773-8.

79. Samoylenko I, Shpynov S, Raoult D, Rudakov N, Fournier PE. Evaluation of Dermacentor species naturally infected with Rickettsia raoultii. Clin Microbiol Infect. 2009;2(15 Suppl):305-6.

80. Wójcik-Fatla A, Zając V, Sawczyn A, Cisak E, Dutkiewicz J. Babesia spp. in questing ticks from eastern Poland: prevalence and species diversity. Parasitol Res. 2015 May 16. [Epub ahead of print] 
81. Siński E, Bajer A, Welc R, Pawełczyk A, Ogrzewalska M, Behnke JM. Babesia microti: prevalence in wild rodents and Ixodes ricinus ticks from the Mazury Lakes District of North-Eastern Poland. Int J Med Microbiol. 2006;296 Suppl 40:137-43.

82. Paziewska A, Zwolińska L, Harris PD, Bajer A, Siński E. Utilisation of rodent species by larvae and nymphs of hard ticks (Ixodidae) in two habitats in NE Poland. Exp Appl Acarol. 2010;50:79-91.

83. Karbowiak G. Kleszcz łąkowy Dermacentor reticulatus - występowanie, biologia i rola jako wektora chorób odkleszczowych. In: Instytut Parazytologii im, editor. Habilitation thesis. Warsaw: Witolda Stefańskiego PAN; 2009.

84. Welc-Faleciak R, Paziewska A, Bajer A, Behnke JM, Siński E. Bartonella spp. infection in rodents from different habitats in the Mazury Lake District, Northeast Poland. Vector Borne Zoonotic Dis. 2008:8:467-74.

85. Rydkina E, Roux V, Rudakov N, Gafarova M, Tarasevich I, Raoult D. New Rickettsiae in ticks collected in territories of the former soviet union. Emerg Infect Dis. 1999:5:811-4.

86. Mediannikov O, Matsumoto K, Samoylenko I, Drancourt M, Roux V, Rydkina E, et al. Rickettsia raoultii sp. nov., a spotted fever group rickettsia associated with Dermacentor ticks in Europe and Russia. Int J Syst Evol Microbiol. 2008:58:1635-9.

87. Ibarra V, Oteo JA, Portillo A, Santibáñez S, Blanco JR, Metola L, et al. Rickettsia slovaca infection: DEBONEL/TIBOLA. Ann N Y Acad Sci. 2006;1078:206-14.

88. Parola P, Rovery C, Rolain JM, Brouqui P, Davoust B, Raoult D. Rickettsia slovaca and R. raoultii in tick-borne Rickettsioses. Emerg Infect Dis. 2009;15:1105-8.

89. Rieg S, Schmoldt S, Theilacker C, de With K, Wölfel S, Kern W, et al. Tickborne lymphadenopathy (TIBOLA) acquired in Southwestern Germany. BMC Infect Dis. 2011;11:167.

90. Chmielewski T, Rudzka D, Fiecek B, Maczka I, Tylewska-Wierzbanowska S. Case of TIBOLA/DEBONEL (tick - borne lymphadenopathy/Dermacentor spp. borne necrosis - erythema - lymphadenopathy) in Poland. Przegl Epidemiol. 2011;65:583-6.

91. Wächter M, Wölfel S, Pfeffer M, Dobler G, Kohn B, Moritz A, et al. Serological differentiation of antibodies against Rickettsia helvetica, $R$. raoultii, $R$. slovaca, $R$. monacensis and $R$. felis in dogs from Germany by a micro-immunofluorescent antibody test. Parasit Vectors. 2015;23(8):126.

92. Márquez FJ. Spotted fever group Rickettsia in ticks from southeastern Spain natural parks. Exp Appl Acarol. 2008;45(3-4):185-94.

93. Stefanoff P, Pfeffer M, Hellenbrand W, Rogalska J, Rühe F, Makówka A, et al Virus detection in questing ticks is not a sensitive indicator for risk assessment of tick-borne encephalitis in humans. Zoonoses Public Health. 2013;60:215-26

94. Cisak E, Wójcik-Fatla A, Zając V, Sroka J, Buczek A, Dutkiewicz J. Prevalence of tick-borne encephalitis virus (TBEV) in samples of raw milk taken randomly from cows, goats and sheep in eastern Poland. Ann Agric Environ Med. 2010;17:283-6

95. Yu C, Achazi K, Möller L, Schulzke JD, Niedrig M, Bücker R. Tick-borne encephalitis virus replication, intracellular trafficking, and pathogenicity in human intestinal Caco-2 cell monolayers. PLoS One. 2014;9:e96957.

96. Dzięgiel B, Kubrak T, Adaszek $Ł$, Dębiak P, Wyłupek D, Bogucka-Kocka A, et al. Prevalence of Babesia canis, Borrelia burgdorferi sensu lato, and Anaplasma phagocytophilum in hard ticks collected from meadows of Lubelskie Voivodship (eastern Poland). Bull Vet Inst Pulawy. 2014;58:29-33.

97. Mátlová L, Halouzka J, Juřicová Z, Hubálek Z. Comparative experimental infection of Ixodes ricinus and Dermacentor reticulatus (Acari: Ixodidae) with Borrelia burgdorferi sensu lato. Folia Parasitol. 1996:43:159-60.

98. Rudolf I, Hubálek Z. Effect of the salivary gland and midgut extracts from Ixodes ricinus and Dermacentor reticulatus (Acari: Ixodidae) on the growth of Borrelia garinii in vitro. Folia Parasitol (Praha). 2003;50:159-60.

99. Johns R, Ohnishi J, Broadwater A, Sonenshine DE, De Silva AM, Hynes WL. Contrasts in tick innate immune responses to Borrelia burgdorferi challenge: immunotolerance in Ixodes scapularis versus immunocompetence in Dermacentor variabilis (Acari: Ixodidae). J Med Entomol. 2001;38:99-107.

100. Grubhoffer L, Golovchenko M, Vancová M, Zacharovová-Slavícková K, Rudenko N, Oliver Jr JH. Lyme borreliosis: insights into tick-/host-borrelia relations. Folia Parasitol (Praha). 2005;52:279-94.

\section{Submit your next manuscript to BioMed Central and take full advantage of:}

- Convenient online submission

- Thorough peer review

- No space constraints or color figure charges

- Immediate publication on acceptance

- Inclusion in PubMed, CAS, Scopus and Google Scholar

- Research which is freely available for redistribution

Submit your manuscript at www.biomedcentral.com/submit 